\title{
Varietal screening of mungbean cultivars for resistance/tolerance against insect pest under Terai Agro ecological zone of West Bengal
}

\author{
SAGAR TAMANG*, P. VENKATARAO AND GAUTAM CHAKRABORTY ${ }^{1}$
}

Department of Agricultural Entomology, Uttar Banga Krishi Viswavidyalaya, Pundibari, COOCH BEHAR (W.B.) INDIA ${ }^{1}$ Department of Agricultural Entomology, Bidhan Chandra Krishi Viswavidyalaya, Mohanpur, NADIA (W.B.) INDIA

\section{ARITCLE INFO \\ Received : 18.01 .2017 \\ Revised : 21.02 .2017 \\ Accepted : 26.02.2017}

KEY WORDS :

Mungbean, Cultivars,

Insect pests, Screening

*Corresponding author:

Email : entotamang@gmail.com

\begin{abstract}
Varietal preference of insect pests on mungbean germplasm was monitored under field conditions at Uttar Banga Krishi Viswavidyalaya, Pundibari, Cooch Behar, West Bengal during the year 2012-13. Five genotypes/lines of mungbean germplasm were screened against insect pest and the germplasms were categorized into resistant and susceptible depending upon severity of pest incidence. The differential responses of mungbean varieties to insect pests were determined and none of the genotype/line was found to be highly resistant to insect pest. During first season, Bireswar (WBM-34-1-1) had less susceptibility to the attack of aphid and thrips gave highest $(558.79 \mathrm{~kg} / \mathrm{ha})$ grain yield followed by Sukumar (WBM-29) with grain yield of $547.47 \mathrm{k} / \mathrm{ha}$. Same trend was observed in case of aphid and thrips incidence during second season of screening. Comparison of resistance among the five tested genotypes against whitefly showed that the lowest (0.23) number of whiteflies per leaf was observed in Sonali (B-1), lower than those of both Bireswar (WNM-34-1-1) and Sukumar (WBM-29), whereas, the highest (1.33/ leaf) was observed in Panna (B-105) during first season. Whereas, in second season lowest (0.65/ leaf) whitefly incidence was observed on Sonali (B-1). highest (1.83/ leaf) whitefly incidence was observed in Sukumar (WBM-29) followed by Panna (B-105) and Bireswar with 1.80 and 1.20 numbers per leaf, respectively. In case pod borer incidence, the lowest (0.03) and the highest (1.18) larval population were observed on cultivar Sonali (B-1) and Sukumar (WBM-29), respectively during first season. Whereas, during second season, among five varieties screened, highest (1.23/ plant) pod borer on Samrat (PDM 24-139) variety followed by Bireswar (WBM34-1-1) and Panna (B-105) by recording pod borer incidence 0.93 and $0.73 /$ plant, respectively. Lowest (0.22/plant) pod borer incidence observed on Sukumar (WBM29 ) variety. Highest (2.20/plant) predatory coccinellid beetle was observed on Bireswar (WBM-34-1-1) followed by Sonali (B-1) and Samrat (PDM 24-139) with 1.89 and 1.25 numbers per plant, respectively. Lowest (0.84/ plant) lady beetle was observed on Panna (B-105) variety during first season. Whereas, during second season highest

Abstract : Contd.........
\end{abstract}

